ISSN 0258-7122 (Print), 2408-8293 (Online)

Bangladesh J. Agril. Res. 41(3): 411-418, September 2016

\title{
EFFECTIVENESS OF SOIL AND FOLIAR APPLICATIONS OF ZINC AND BORON ON THE YIELD OF TOMATO
}

\author{
S. SUltanA ${ }^{1}$, H. M. NASER ${ }^{2}$, S. AKHTER ${ }^{3}$ AND R. A. BEGUM ${ }^{4}$
}

\begin{abstract}
Field experiment was carried out for two consecutive years to study the effectiveness of soil and foliar application of micronutrients on the yield of tomato (Lycopersicon esculentum Mill.) at the Bangladesh Agricultural Research Institute (BARI), Joydebpur, Gazipur. The micronutrients zinc ( $\mathrm{Zn}$ ) in the form of zinc sulphate $\left(\mathrm{ZnSO}_{4} .7 \mathrm{H}_{2} \mathrm{O}\right)$ at the rate of $0.05 \%$ and boron $(\mathrm{B})$ in the form of boric acid $\left(\mathrm{H}_{3} \mathrm{BO}_{3}\right)$ at the rate of $0.03 \%$ were applied as foliar spray at three different stages of plant growth i.e (i) before flower initiation; (ii) after fruit set when it becomes approximately marble sized; and (iii) at 20 days interval of second spray. The tomato yield and its contributing yield traits were significantly affected by foliar fertilizer treatments as against soil application of $\mathrm{B}$ and $\mathrm{Zn}$ fertilizers. Among various treatments, foliar application of $\mathrm{Zn}(0.05$ $\%)+\mathrm{B}(0.03 \%)$ produced maximum fruit yield $\left(85.5\right.$ and $81.7 \mathrm{t} \mathrm{ha}^{-1}$ in 2013 and 2014 , respectively) while the control no application of $\mathrm{Zn}(0.0)$ and $\mathrm{B}(0.0)$ produced 66.8 and $60.7 \mathrm{t} \mathrm{ha}^{-1}$ in 2013 and 2014, respectively and it was statistically identical with soil application of B and $\mathrm{Zn} @ 2$ and $6 \mathrm{~kg} \mathrm{ha}^{-1}\left(\mathrm{~T}_{5}\right)$ respectively. The increment of yield was 19.2 to $31.1 \%$ and 7.57 to $18.3 \%$, respectively, over control and soil application. The integrated use of foliar application of micronutrients and soil application of macronutrients are recommended to enhance tomato yield.
\end{abstract}

Keywords: Foliar applications, zinc, boron, tomato and yield.

\section{Introduction}

Micronutrient deficiencies are not only hampering crop productivity but also are deteriorating quality. The low micronutrient feed and food stuffs are causing health hazards in human beings and animals. Micronutrient acts as catalyst in the uptake and use of certain macronutrients (Phillips, 2004). Fruit size and quality as well as quality of some crops, are improved with micronutrient ( $\mathrm{Zn}$ and $\mathrm{B}$ ) use.

Tomato (Lycopersicon esculentum Mill.) is an important vegetable crop, which belongs to the family Solanaceae and also used in daily diet due to its good taste. The yield of tomato has declined due to micronutrient deficiency (Ejaz et al., 2011). Excess use of phosphate fertilizers in soils with micronutrients

${ }^{1}$ Scientific Officer, Soil Science Division, Bangladesh Agricultural Research Institute (BARI), Joydebpur, Gazipur-1701, ${ }^{2 \& 3}$ Principal Scientific Officer, Soil Science Division, BARI, Joydebpur, Gazipur-1701, ${ }^{4}$ Chief Scientific Officer and Head, Soil Science Division, BARI, Joydebpur, Gazipur-1701, Bangladesh. 
deficiencies is causing imposed deficiency of micronutrients in the plants (Salimpour et al., 2010; Khorgamy and Farnis, 2009; Hopkins and Ellsworth, 2003). With increasing utilization of chemical fertilizer environmental pollution has increased remarkably.

In spite of adequate application of NPK fertilizer, normal growth of high yielding varieties could not be obtained due to little or no application of micronutrients. High fertilizer responsive varieties express their full yield potential when trace elements are applied along with NPK fertilizers (Nataraja et al., 2006). Chaudry et al. (2007) stated that micronutrients especially zinc ( $\mathrm{Zn}$ ) and boron (B) significantly increased the crop yield over control when applied single or in combination with each other, while Mandal et al. (2007) observed significant positive interaction between fertilizer treatments and physiological stages of crop growth. Considering the aforementioned facts, it is felt necessary to study the factors responsible for fertilizer efficiency improvement.

Keeping in view the key role played by $\mathrm{Zn}$ and $\mathrm{B}$ nutrition in plant growth, this study is designed to find out the suitable dose and method of $\mathrm{Zn}$ and $\mathrm{B}$ application for tomato production. The objectives of this research, therefore, were (i) to identify a suitable combination of $\mathrm{Zn}$ and $\mathrm{B}$ fertilization for tomato production; and (ii) to compare the effects of the methods of micronutrient application foliar vs. soil fertilization on yield of tomato.

\section{Materials and Method}

Field research was conducted at micronutrient experimental field of Soil Science Division, Bangladesh Agricultural Research Institute (BARI), Joydebpur, Gazipur, located at $23^{\circ} 59^{\prime} 26^{\prime \prime} \mathrm{N}$ and $90^{\circ} 24^{\prime} 52^{\prime \prime} \mathrm{E}$. The experiment was laid out in a RCB design with three replications. The unit plot was $3 \mathrm{~m} \times 3 \mathrm{~m}$. Two adjacent unit plots were separated by $75 \mathrm{~cm}$ and $1 \mathrm{~m}$ space was given between the blocks. Land was separated into two parts viz., a. Foliar application and b. Soil application. Part (a) consisted of 12 unit plots and (b) part consisted of 3 unit plots. During final land preparation on November 2013 and 2014, fertilizers were applied to the soil at the rate of $\mathrm{N}_{140}, \mathrm{P}_{45}, \mathrm{~K}_{90}$ and $\mathrm{S}_{18} \mathrm{~kg} \mathrm{ha}^{-1}$ as urea, triple supper phosphate, muriate of potash and gypsum, respectively, in both (a) and (b) applications plot. For soil fertilization, at the same time B and $\mathrm{Zn}$ were applied at the rates of 2 and $6 \mathrm{~kg} \mathrm{ha}^{-1}$ in soil application part (b). BARI Tomato 15 was used in this experiment. Healthy and uniform sized 30 days old seedlings were transplanted at $60 \mathrm{~cm} \times 50 \mathrm{~cm}$ spacing and total plant per plot was 30 . Inter cultural operations were done as and when needed.

\section{Foliar application}

To study the effect of $\mathrm{Zn}$ and B as foliar spray on growth and yield of tomato, two micronutrients $\mathrm{Zn}$ and $\mathrm{B}$ at a single rate alone and at different combinations 
in the form of zinc sulphate $\left(\mathrm{ZnSO}_{4} .7 \mathrm{H}_{2} \mathrm{O}\right)$ containing $23 \% \mathrm{Zn}$ at the rate of 0.05 $\%$ and boric acid $\left(\mathrm{H}_{3} \mathrm{BO}_{3}\right)$ having $18 \%$ boron at the rate of $0.03 \%$ were applied as foliar spray at three different stages of plant growth (i) before flower initiation; (ii) after fruit set when it becomes approximately marble sized; and (iii) at 20 days interval of second spray. The treatment combinations of foliar spray of $\mathrm{Zn}$ and $\mathrm{B}$ were $\mathrm{T}_{1}: \mathrm{Zn}(0.0 \%)+\mathrm{B}(0.0 \%)$ as control; $\mathrm{T}_{2}: \mathrm{Zn}(0.05 \%)+\mathrm{B}(0.0 \%)$; $\mathrm{T}_{3}: \mathrm{Zn}(0.0 \%)+\mathrm{B}\left(0.03 \%\right.$; and $\mathrm{T}_{4}: \mathrm{Zn}(0.05 \%)+\mathrm{B}(0.03 \%)$. Soil fertilization treated as $\mathrm{T}_{5}: \mathrm{Zn}(6)$ and $\mathrm{B}(2) \mathrm{kg} \mathrm{ha}^{-1}$ was applied basal as stated above.

The solution of all treatments were prepared and contained urea at the rate of $0.08 \%$ to activate mineral absorption and surf (detergent) used as wetting agent at the rate of $0.01 \%$ for reducing contact angle between the liquid and leaf surface (Sajid et al., 2010). The volume of water 1.0 liter plant ${ }^{-1}$ was estimated (3 split at three different stages of plant growth viz., $300 \mathrm{ml}+300 \mathrm{ml}+400 \mathrm{ml}$ of solution, approximate) to wet completely the tomato plant. The spray solution was prepared separately on the basis of $2.17 \mathrm{mg}$ and $1.67 \mathrm{mg}$ of $\mathrm{ZnSO}_{4} .7 \mathrm{H}_{2} \mathrm{O}$ and $\mathrm{H}_{3} \mathrm{BO}_{3}$ in 1.0 liter of water, respectively. Urea at the rate of $1.74 \mathrm{mg}$ and surf 0.1 mg liter ${ }^{-1}$ as a wetting agent were applied along with each treatment. The foliar spray contained $\mathrm{Zn}(0.05 \%)$ and $\mathrm{B}(0.03 \%)$, amended with surfactant to curtail water desertion during the spray process, to ensure the nutrients adhered to the leaf surface, and to maximize uptake by foliage. Data were collected on fruit diameter, fruit height, individual fruit weight and fruit yield of tomato and recorded data were analyzed statistically and means were compared by Tukey's multiple comparisons test using Excel Statistics version 4.0 (Esumi Co. Ltd., Tokyo, Japan).

To compare different treatments combination with control/soil application treatment the following equation was applied (Rhaman et al., 2011).

$$
\begin{aligned}
\operatorname{MBCR}(\text { Over control }) & =\frac{\text { Gross return }\left(\mathrm{T}_{1}\right)-\operatorname{Gross} \text { return }\left(\mathrm{T}_{0}\right)}{\operatorname{VC}\left(\mathrm{T}_{1}\right)-\mathrm{VC}\left(\mathrm{T}_{0}\right)} \\
& =\frac{\text { Added benefit (over control })}{\text { Added cost }(\text { over control })}
\end{aligned}
$$

Where, $\mathrm{T}_{\mathrm{i}}=\mathrm{T}_{1}, \mathrm{~T}_{2}, \mathrm{~T}_{4}, \mathrm{~T}_{5}$ treatments; $\mathrm{T}_{0}=$ Control treatment; $\mathrm{VC}=$ Variable cost; and Gross return $=$ Yield $\times$ price .

\section{Methods of chemical analysis of soil}

Initial soil samples collected from $0-15 \mathrm{~cm}$ depth prior to fertilizer application, were analyzed for all important soil parameters using standard procedures (Table 1). Soil $\mathrm{pH}$ was measured by a combined glass calomel electrode. Organic carbon was determined by the wet oxidation method. Total $\mathrm{N}$ was determined by a modified Kjeldahl method. Calcium $(\mathrm{Ca})$, magnesium $(\mathrm{Mg})$ and $\mathrm{K}$ were 
determined by $\mathrm{NH}_{4} \mathrm{OAc}$ extractable method, copper $(\mathrm{Cu})$, iron $(\mathrm{Fe})$ and zinc $(\mathrm{Zn})$ were determined by DTPA extraction followed by AAS reading. Boron (B) was determined by $\mathrm{CaCl}_{2}$ extraction method. Available $\mathrm{P}$ was determined by the Bray and Kurtz method while $\mathrm{S}$ was determined using the turbidimetric method with $\mathrm{BaCl}_{2}$.

\section{Results and discussion}

Experimental field soil was neutral in reaction $\mathrm{pH}$ (7.08), low in organic matter $(1.09 \%)$, total nitrogen content $(0.06 \%)$ and exchangeable potassium $(0.08 \mathrm{meq}$ $100 \mathrm{~g})$, however quite high in available phosphorus $\left(15.1 \mu \mathrm{g} \mathrm{g}^{-1}\right)$. The status of B $\left(0.13 \mu \mathrm{g} \mathrm{g}^{-1}\right)$ was below the critical level and $\mathrm{Zn}\left(2.60 \mu \mathrm{g} \mathrm{g}^{-1}\right)$ was higher than the critical level (Table 1). In general terrace soil (Chiata Series) of Joydebpur is acidic in nature. But the soil of experimental field does not belong to terrace soil. Soil development in this experimental field has been made with river-bed soil from the nearby areas.

Table 1. Initial properties of the soil samples of experimental field

\begin{tabular}{|c|c|c|c|c|c|c|c|c|c|c|c|c|}
\hline \multirow{2}{*}{$\begin{array}{c}\text { Soil } \\
\text { Properties }\end{array}$} & \multirow{2}{*}{$\mathrm{pH}$} & \multirow{2}{*}{$\begin{array}{c}\mathrm{OM} \\
\%\end{array}$} & $\mathrm{Ca}$ & $\mathrm{Mg}$ & $\mathrm{K}$ & \multirow{2}{*}{$\begin{array}{c}\text { Total } \\
\mathrm{N} \\
\% \\
\end{array}$} & $\mathrm{P}$ & $S$ & B & $\mathrm{Cu}$ & $\mathrm{Fe}$ & $\mathrm{Zn}$ \\
\hline & & & & $100 \mathrm{~g}$ & & & \multicolumn{6}{|c|}{$\mu \mathrm{g} \mathrm{g}^{-1}$} \\
\hline Result $^{\S}$ & 7.08 & 1.09 & 6.88 & 2.26 & 0.08 & 0.06 & 15.1 & 3.33 & 0.13 & 2.01 & 11.2 & 2.60 \\
\hline $\begin{array}{c}\text { Critical } \\
\text { level }\end{array}$ & - & - & 2.0 & 0.5 & 0.12 & - & 10 & 10 & 0.2 & 0.2 & 4.0 & 0.6 \\
\hline
\end{tabular}

The tomato yield and its contributing yield traits were significantly affected by foliar fertilizer treatments as against soil application of B and $\mathrm{Zn}$ fertilizers, as depicted by the significance of F-values from the analysis of variance (Tables 2 and 3). A significant variation was observed for tomato yield when the plants treated with foliar application of $\mathrm{Zn}$ and $\mathrm{B}$ alone or either in combinations. Maximum yield (85.5 and $81.7 \mathrm{t} \mathrm{ha}^{-1}$ in 2013 and 2014, respectively) was produced, when plants were treated with $0.05 \%$ of $\mathrm{Zn}$ in combination with $0.03 \%$ of B, followed by plants sprayed with $0.05 \%$ of $\mathrm{Zn}$ alone $\left(84.3 .1\right.$ and $76.8 \mathrm{tha}^{-1}$ in 2013 and 2014, respectively). Minimum fruit yield (66.8 and $60.7 \mathrm{t} \mathrm{ha}^{-1}$ in 2013 and 2014, respectively) was produced by untreated plants - control. Comparatively lower yield was recorded in plants which sprayed with $0.03 \%$ of B alone than that of plants sprayed with $0.05 \% \mathrm{Zn}$. Soil of this experiment is neutral and content of $\mathrm{Zn}$ was $2.6 \mu \mathrm{g} \mathrm{g}^{-1}$, which was higher than the critical limit. But due to neutrality $\mathrm{Zn}$ is unavailable to uptake by plant. For that reason, only B application did not help maximize the yield of tomato. Mousavi (2011) reported that soils with high $\mathrm{pH}$, in this type of soils solubility of micronutrients except $\mathrm{B}$ is less and cause decline uptake of these elements by plant. On the other hand, higher yield in treatment sprayed with $0.05 \% \mathrm{Zn}$ alone, perhaps these increases in fruit yields were due to the significant increase in leaf $\mathrm{Zn}$ concentration which in turn induced more 
flowering and minimized the fruit drop in tomato plant (Garcia et al. 1984). Higher yield in foliar application of $\mathrm{Zn}$ without $\mathrm{B}$ application might be due to foliar application of zinc increased B uptake by plants in the soils with sufficient stores (Rengel et al., 1998). The supply of B needed for reproductive growth in many crops is more needed than that needed for vegetative growth (Mengel and Kirkby, 1982; Marschner, 1986; Hanson, 1991).

Table 2. Agronomic traits of tomato as affected by foliar and soil application of $\mathrm{Zn}$ and $B$ during 2013

\begin{tabular}{|c|c|c|c|c|c|}
\hline \multirow[b]{2}{*}{ Treatment } & \multicolumn{3}{|c|}{ Agronomic traits } & \multicolumn{2}{|c|}{ Fruit yield } \\
\hline & $\begin{array}{c}\text { Fruit } \\
\text { diameter } \\
(\mathrm{cm})\end{array}$ & $\begin{array}{l}\text { Fruit height } \\
\qquad(\mathrm{cm})\end{array}$ & $\begin{array}{l}\text { Individual } \\
\text { fruit wt. (g) }\end{array}$ & $\begin{array}{c}\text { Yield } \\
\left(\mathrm{kg} \mathrm{plot}^{-1}\right)^{*}\end{array}$ & $\begin{array}{l}\text { Yield } \\
\left(\mathrm{t} \mathrm{ha}^{-1}\right)\end{array}$ \\
\hline $\begin{array}{l}\text { 1. } \mathrm{Zn}(0.0)+\mathrm{B}(0.0) \\
\text { - control }\end{array}$ & $4.18 \pm 0.26 c$ & $5.07 \pm 0.32 \mathrm{c}$ & $55.8 \pm 10.2 c$ & $60.1 \pm 8.72 c$ & $66.8 \pm 9.68 \mathrm{c}$ \\
\hline $\begin{array}{l}2 . \mathrm{Zn}(0.05 \%)+\mathrm{B} \\
(0.0 \%) \text { foliar } \\
\text { application }\end{array}$ & $4.59 \pm 0.19 \mathrm{ab}$ & $5.32 \pm 0.26 b$ & $65.6 \pm 5.09 \mathrm{ab}$ & $75.9 \pm 10.7 \mathrm{a}$ & $84.3 \pm 11.9 \mathrm{a}$ \\
\hline $\begin{array}{l}\text { 3. } \mathrm{Zn}(0.0 \%)+\mathrm{B} \\
(0.03 \%) \text { foliar } \\
\text { application }\end{array}$ & $4.44 \pm 0.45 \mathrm{ab}$ & $5.29 \pm 0.28 b c$ & $60.9 \pm 8.62 b c$ & $72.1 \pm 10.1 \mathrm{ab}$ & $80.1 \pm 11.3 \mathrm{ab}$ \\
\hline $\begin{array}{l}\text { 4. } \mathrm{Zn}(0.05 \%)+\mathrm{B} \\
(0.03 \%) \text { foliar } \\
\text { application }\end{array}$ & $4.68 \pm 0.19 a$ & $5.41 \pm 0.18 \mathrm{a}$ & $68.5 \pm 6.26 \mathrm{a}$ & $77.0 \pm 11.5 \mathrm{a}$ & $85.5 \pm 12.8 \mathrm{a}$ \\
\hline $\begin{array}{l}\text { 5. } \mathrm{Zn}(6)+\mathrm{B}(2) \text { soil } \\
\text { application }\left(\mathrm{kg} \mathrm{ha}^{-1}\right)\end{array}$ & $4.37 \pm 0.22 b$ & $5.18 \pm 0.61 b c$ & $59.3 \pm 6.03 b c$ & $67.4 \pm 7.07 \mathrm{bc}$ & $74.9 \pm 7.9 \mathrm{bc}$ \\
\hline $\mathrm{CV}(\%)$ & 4.96 & 7.06 & 12.1 & 14.7 & - \\
\hline
\end{tabular}

Mean values in the same column followed by the same letters are not significantly different $(P<0.05)$. ${ }^{*}$ Plot size: $9 \mathrm{~m}^{-2}$.

Plants sprayed with $\mathrm{Zn}$ in combination with $\mathrm{B}$ or alone $\mathrm{Zn}$ showed maximum response in fruit diameter, fruit height and individual fruit weight compared with control and soil application of both elements. Gitte et al. (2005) observed that the combined application of $\mathrm{Zn}$ and $\mathrm{B}$ exhibited yield increases over unfertilized controls. The data given in Table 2 indicated that micronutrient and their foliar doses had significant effect on fruit yield of tomato. Among various treatments, foliar application of $\mathrm{Zn}(0.05 \%)+\mathrm{B}(0.03 \%)\left(\mathrm{T}_{4}\right)$ produced maximum grain yield $\left(81.3 \mathrm{t} \mathrm{ha}^{-1}\right)$ while the control $\left(\mathrm{T}_{1}\right)$ no use of $\mathrm{Zn}(0.0)$ and $\mathrm{B}(0.0)$ produced $63.6 \mathrm{tha}$ 1 . And $\mathrm{T}_{4}$ was statistically differed with soil application of B and $\mathrm{Zn} @ 2$ and $6 \mathrm{~kg}$ $\mathrm{ha}^{-1}\left(\mathrm{~T}_{5}\right)$, respectively. The foliar application of $\mathrm{Zn}$ in combination with $\mathrm{B}$ and $\mathrm{Zn}$ alone was more effective than the soil application of both fertilizers. When compared the fruit yield from control or soil application plot with foliar applications the increment of yield were 19.2 to $31.1 \%$ and 7.57 to $18.3 \%$, respectively, over 
control and soil application (Table 4). The maximum marginal benefit-cost ratio (MBCR) of 211 was obtained by application of $\mathrm{Zn}$ in combination with $\mathrm{B}$ followed by $\mathrm{Zn}$ alone (181) which are almost on par at each other compared to control which recorded minimum gross returns of Tk. $957000 \mathrm{ha}^{-1}$.

Table 3. Agronomic traits of tomato as affected by foliar and soil application of $\mathrm{Zn}$ and B during 2014

\begin{tabular}{|c|c|c|c|c|c|}
\hline \multirow[b]{2}{*}{ Treatment } & \multicolumn{3}{|c|}{ Agronomic traits } & \multicolumn{2}{|c|}{ Fruit yield } \\
\hline & $\begin{array}{c}\text { Fruit } \\
\text { diameter } \\
(\mathrm{cm})\end{array}$ & $\begin{array}{l}\text { Fruit height } \\
\qquad(\mathrm{cm})\end{array}$ & $\begin{array}{l}\text { Individual } \\
\text { fruit wt. }(\mathrm{g})\end{array}$ & $\begin{array}{c}\text { Yield }^{\text {* }} \\
\left(\operatorname{kg~plot}^{-1}\right)\end{array}$ & $\begin{array}{l}\text { Yield } \\
\left(\mathrm{t} \mathrm{ha}^{-1}\right)\end{array}$ \\
\hline $\begin{array}{l}\text { 1. } \mathrm{Zn}(0.0)+\mathrm{B}(0.0)- \\
\text { control }\end{array}$ & $3.72 \pm 0.14 b$ & $4.26 \pm 0.32 b$ & $49.3 \pm 3.46 b$ & $54.6 \pm 2.12 b$ & $60.7 \pm 2.35 b$ \\
\hline $\begin{array}{l}\text { 2. } \mathrm{Zn}(0.05 \%)+\mathrm{B}(0.0 \%) \\
\text { foliar application }\end{array}$ & $4.55 \pm 0.54 \mathrm{a}$ & $5.09 \pm 0.41 \mathrm{a}$ & $63.1 \pm 5.99 a$ & $69.1 \pm 6.64 \mathrm{ab}$ & $76.8 \pm 7.38 \mathrm{ab}$ \\
\hline $\begin{array}{l}\text { 3. } \mathrm{Zn}(0.0 \%)+\mathrm{B}(0.03 \%) \\
\text { foliar application }\end{array}$ & $4.37 \pm 0.24 \mathrm{ab}$ & $4.91 \pm 0.27 \mathrm{ab}$ & $54.9 \pm 5.14 b$ & $64.7 \pm 2.52 \mathrm{ab}$ & $71.9 \pm 2.80 \mathrm{ab}$ \\
\hline $\begin{array}{l}\text { 4. } \mathrm{Zn}(0.05 \%)+\mathrm{B} \\
\text { (0.03\%) foliar } \\
\text { application }\end{array}$ & $4.63 \pm 0.31 \mathrm{a}$ & $5.17 \pm 0.34 \mathrm{a}$ & $67.2 \pm 4.44 \mathrm{a}$ & $73.5 \pm 8.68 \mathrm{a}$ & $81.7 \pm 9.65 \mathrm{a}$ \\
\hline $\begin{array}{l}\text { 5. Zn (6) + B (2) soil } \\
\text { application }\left(\mathrm{kg} \mathrm{ha}^{-1}\right)\end{array}$ & $4.25 \pm 0.41 \mathrm{ab}$ & $4.79 \pm 0.49 \mathrm{ab}$ & $51.0 \pm 6.10 \mathrm{~b}$ & $59.8 \pm 4.89 \mathrm{ab}$ & $66.4 \pm 5.44 \mathrm{ab}$ \\
\hline $\mathrm{CV}(\%)$ & 6.64 & 5.90 & 5.86 & 9.42 & - \\
\hline
\end{tabular}

Mean values in the column followed by the same letters are not significantly different $(P<0.05)$. Plot size: $9 \mathrm{~m}^{-2}$

Table 4. Yield comparison between foliar and soil application of $\mathrm{Zn}$ and $\mathrm{B}$ and their economics of two years average

\begin{tabular}{|c|c|c|c|c|c|c|c|}
\hline \multirow{2}{*}{ Treatment } & \multirow{2}{*}{$\begin{array}{c}\text { Fruit } \\
\text { yield } \\
\left(\mathrm{t} \mathrm{ha}^{-1}\right)\end{array}$} & \multicolumn{2}{|c|}{$\begin{array}{c}\text { Yield increased } \\
(\%)\end{array}$} & \multirow{2}{*}{$\begin{array}{c}\text { Variable } \\
\text { cost }^{\S} \\
\left(\mathrm{Tk} \text { ha }^{-}\right. \\
1)\end{array}$} & \multirow{2}{*}{$\begin{array}{c}\text { Gross } \\
\text { return } \\
\left(\begin{array}{c}\text { Tk ha } \\
1\end{array}\right)\end{array}$} & \multicolumn{2}{|c|}{ MBCR } \\
\hline & & \begin{tabular}{|c|} 
Over \\
control
\end{tabular} & \begin{tabular}{|c|} 
Over soil \\
application
\end{tabular} & & & \begin{tabular}{|c|} 
over \\
control
\end{tabular} & \begin{tabular}{|c|} 
over soil \\
application
\end{tabular} \\
\hline $\begin{array}{l}\text { 1. } \mathrm{Zn}(0.0)+\mathrm{B}(0.0)- \\
\text { control }\end{array}$ & 63.8 & - & -10.8 & 14595 & 957000 & - & $(16.0)$ \\
\hline $\begin{array}{l}\text { 2. } \mathrm{Zn}(0.05 \%)+\mathrm{B}(0.0 \%) \\
\text { foliar application }\end{array}$ & 80.6 & 26.4 & 14.0 & 15988 & 1209000 & 181 & -29.2 \\
\hline $\begin{array}{l}\text { 3. } \mathrm{Zn}(0.0 \%)+\mathrm{B}(0.03 \%) \\
\text { foliar application }\end{array}$ & 76.0 & 19.2 & 7.57 & 15991 & 1140000 & 131 & -15.7 \\
\hline $\begin{array}{l}\text { 4. } \mathrm{Zn}(0.05 \%)+\mathrm{B}(0.03 \%) \\
\text { foliar application }\end{array}$ & 83.6 & 31.1 & 18.3 & 16004 & 1254000 & 211 & -38.2 \\
\hline $\begin{array}{l}\text { 5. } \mathrm{Zn}(6)+\mathrm{B}(2) \text { soil } \\
\text { application }\left(\mathrm{kg} \mathrm{ha}^{-1}\right)\end{array}$ & 70.7 & 10.8 & - & 21070 & 1060500 & (16.0) & - \\
\hline
\end{tabular}

${ }^{\S}$ Variable cost considering only fertilizer and wage rate

Input prices $\left(\mathrm{Tk} \mathrm{kg}^{-1}\right)$ : Urea: 16; TSP: 25; MoP: 15; Gypsum: 15; Zincsulphate: 140;

Boric acid: 240.

Wage rate: $230 \mathrm{Tk}$

Out put price $\left(\mathrm{Tk} \mathrm{kg}^{-1}\right)$ : Tomato: 15 


\section{Conclusion}

Foliar applications of micronutrients are more suitable than the soil application, due to the rapid overcoming on deficient, easy to use, reducing the toxicity caused by accumulation and preventing of elements stabilization in the soil. The integrated use of foliar application of micronutrients and soil application of macronutrients is recommended to enhance tomato yield. This paper also suggests that foliar application of micronutrients; particularly of $\mathrm{Zn}$ and $\mathrm{B}$ is an effective technology for increasing the yield of tomato.

\section{Reference}

Chaudry, E.H., V. Timmer, A.S. Javed and M.T. Siddique. 2007. Wheat response to micronutrients in rainfed areas of Punjab. Soil \& Environ. 26:97-101.

Ejaz, M., R. Waqas, M. Butt, S.U. Rehman and A. Manan. 2011. Role of macro-nutrients and micro-nutrients in enhancing the quality of tomato. Int. J. Agron. Vet. Med. Sci. 5: 401-404.

Gitte, A.N., S.R. Patil and M.A. Tike. 2005. Influence of zinc and boron on biochemical and yield characteristics of sunflower. Ind. J. of Plant Physiol. 10:400-403.

Garcia, A., N.E. Haydar and C. Ferrer. 1984. Influence of $\mathrm{Zn}$ and $\mathrm{Mn}$ on the physiological behavior and yields of Valencia oranges. Center Agricola. Instt. Superior Agricola Ciego de Avila, Cuba. 10: 57-58.

Hanson, E.J. 1991. Movement of boron out of tree fruit leaves. HortScience. 26:271-273.

Hopkins, B. and J. Ellsworth. 2003. Phosphorus nutrition in potato production. Idaho Potato Conference.

Khorgamy, A. and A. Farnia. 2009. Effect of phosphorus and zinc fertilisation on yield and yield components of chick pea cultivars. African Crop Science Conference Proceedings 9: 205-208.

Mandal, A., A.K. Patra, D. Singh, A. Swarup and R.E. Masto. 2007. Effect of long-term application of manure and fertilizer on biological and biochemical activities in soil during crop development stages. Bioresour. Technol. 98:3585-3592.

Mengel, K. and E.A. Kirkby. 1982. Principles of plant nutrition. International Potash Institute. Bern, Switzerland.

Marschner, H. 1986. Mineral nutrition of higher plants. Academic Press, San Diego, CA.

Mousavi, S.R., M. Galavi and G. Ahmadvand. 2007. Effect of zinc and manganese foliar application on yield, quality and enrichment on potato (Solanum tuberosum L.). Asian J. Plant Sc. 6: 1256-1260.

Nataraja, T.H., A.S. Halepyati, B.T. Pujari and B.K. Desai. 2006. Influence of phosphorus levels and micronutrients on the physiological parameters of wheat. Karnataka J. Agri. Sci. 19: 685-687

Phillips, M. 2004. Economic benefit from using micronutrients for the farmer and the fertilizer producer. IFA. International Symposium on Micronutrients. Feb. 23-25, 2004. New Delhi, India. 
Rengel, Z., V. Romheld and H. Marschner. 1998. Uptake of zinc and iron by wheat genocatypes differing in tolerance to zinc deficiency. J. Plant Physiol. 142: 433-438.

Rahman M. H., M. R. Islam, M. Jahiruddin and M.Q. Haque. 2011. Economics of fertilizer use in the Maize-Mungbean/Dhaincha-T.aman rice cropping pattern. $J$. Bangladesh Agril. Univ. 9(1): 37-42.

Salimpour, S., K. Khavazi, H. Nadian, H. Besharati and M. Miransari. 2010 Enhancing phosphorous availability to canola (Brassica napus L.) using $\mathrm{P}$ solubilizing and sulfur oxidizing bacteria, Aust. J. Crop Sci. 4(5): 330-334.

Sajid M., Ali N. Abdur-Rab, M. Arif, L. Ferguson and M. Ahmed. 2010. Effect of foliar application of $\mathrm{Zn}$ and $\mathrm{B}$ on fruit production and physiological disorders in sweet orange cv. Blood Orange. Sarhad J. Agric. 26(3):355-360. 